NBER WORKING PAPER SERIES

PRIVATE PENSIONS AND INFLATION

Martin Feldstein

Working Paper No. $\underline{568}$

NATIONAL BUREAU OF ECONOMIC RESEARCH

1050 Massachusetts Avenue

Cambridge MA 02138

October 1980

This paper was presented at the annual meeting of the American Economic Association, 6 September 1980. It is part of the NBER's projects on Pensions and Inflation. This work has benefited from discussion with other participants in that study, especially Zvi Bodie. I am grateful to the National science Foundation and the IBBER for support. The views expressed here are ny own and should not be attributed to any organization. 


\begin{abstract}
Much of the recent discussion about the relation between pensions and inflation has emphasized the adverse impact that the unexpected rise in inflation had on pension recipients and on the performance of pension funds during the past 15 years. In contrast, the present paper focuses on the way that pensions are likely to evolve in response to the expectation of continued inflation in the future and the uncertainty about the rate of inflation. The analysis concludes that continued inflation is likely to alter the form of private pensions (in the direction of partial indexing) and the nature of pension funding (away from long-term bonds) but that continued inflation is also likely to induce pensions to finance a growing share of retirement consumption.
\end{abstract}

Martin Feldstein National Bureau of Economic Research 1050 Massachusetts Avenue Cambridge, Massachusetts 02138

(617) 868-3905 


\title{
Private Pensions and Inflation
}

\author{
Martin Feldstein*
}

Private pensions play a central role in capital accumulation in the United States. Like every other aspect of capital accumulation, the pension system can be profoundly affected by inflation. Even fully anticipated inflation is far from neutral in its effects because of the fiscal environment within which pensions function. The uncertainty of future inflation can have major additional effects.

Much of the recent discussion about the relation between pensions and inflation has emphasized the adverse impact that the unexpected rise in inflation during the past 15 years has had on pension recipients and on the performance of pension funds. In contrast, the present paper focuses on the way that pensions are likely to evolve in response to the expectation of continued inflation in the future and to the uncertainty about the rate of inflation. The first section discusses how expected inflation will influence the size and composition of pension assets. The second section considers the relation between inflation and the structure of pension benefits. The implication of the uncertainty of future inflation is the subject of the third section.

Unlike the pessimism of much of the recent discussion of the effect of inflation on pensions, my own conclusion is that the private pension system can

* Professor of Economics, Harvard University, and President, National Bureau of Economic Research. This paper was presented at the annual meeting of the American Economic Association, 6 September 1980. It is part of the NBER Study of Private and Public Pensions. This work has benefited from discussion with other participants in that study, expecially Zvi Bodie. I am grateful to the National Science Foundation and the NBER for support. The views expressed here are my own and should not be attributed to any organization. 
continue to function effectively in an inflationary economy. ${ }^{1}$ The unfortunate effects that occurred when inflation, caught pensioners and pension fund managers by surprise should not be confused with an inability to adjust to future conditions, even uncertain future conditions.2 As I shall explain, the persistence of a high rate of inflation is likely to increase the share of total saving that goes into private pensions. Since the tax treatment of pension contributions allows individuals to save in this way for retirement on the same terms that they would under a consumption tax, ${ }^{3}$ the existence of the private pension system may be one of the few things that prevents the national saving rate from going even lower in the current inflationary environment.

\section{Expected Inflation, Asset Yields and Pension Saving}

Although inflation reduces the real net return that portfolio investors as a whole earn for supplying capital to nonfinancial corporations, different classes of portfolio investors are affected very differently. 4 In previous papers, I stressed that it is important to distinguish households and

1 More specifically, the private pension system can function effectively in an inflationary environment unless the inflation rate is so high or so uncertain that the financial markets themselves no longer function.

2 When Alicia Munnell (1979, p. 26) compares the rates of return earned by pension funds with the inflation rate and concludes that the pension funds cannot keep pace with inflation, she fails to separate the effect of unexpected inflation increases that have depressed total portfolio yields from the permanent effect of expected inflation.

3 This is true only if the limits on pension contributions or pension benefits are not binding.

4 See Feldstein and Lawrence Summers (1976) for evidence on the effects of inflation on after-tax rates of return in general and the variety of individual tax rates. 
tax-free institutions in a general equilibrium analysis of the effect of inflation on asset prices (Feldstein, 1980a, 1980b). Now I want to look at the other side of that coin: the implication of investor diversity and yield differences for private pensions.

More specifically, this section examines how the interaction of expected inflation and taxes influences (a) the real yield that pensions can expect to earn; (b) the desirability of pension saving vis-á-vis direct saving by households; and (c) the mix of assets held by pension funds. The emphasis in this section is on steady state analysis in which expected asset yields are constant and expectations are fulfilled.

The impact of expected inflation on pension funds depends on the mix of assets that are available and in which pension funds invest. Currently, pension fund assets are divided approximately evenly between corporate equities and nominal credit market instruments. It is analytically useful, however, to begin by considering the "pure equity" and "pure debt" cases separately.

\subsection{An Equity-Only Economy}

Consider first an economy in which there is no debt. Corporations finance their investments by issuing equity and reinvesting retained earnings. Pension funds invest only in corporate equities.

With the existing U.S. tax rules, inflation would unambiguously reduce the return that firms could earn on equity. ${ }^{l}$ Although this extra inflation-

1 This results from historic cost depreciation and the remaining use of FIFO inventory accounting. The mitigating effect of deducting nominal interest payments is temporarily ruled out by assumption. 
induced tax at the corporate level affects both households and pensions, the after-tax yield to households is further depressed by the tax that must be paid on nominal capital gains. 1 Thus inflation unambiguously reduces the yield on equities to pensions by less than the reduction in the yield on equities held directly by households.

This difference is independent of the short-run capitalization effect and the longer-run capital accumulation effect. A rise in the expected inflation rate reduces the net-of-tax earnings per unit of capital. Since the share price per unit of capital falls to capitalize this reduction in earnings, the yield per dollar of equity capital falls much less. ${ }^{2}$ In the longer run, the lower share price per unit of capital induces a reduction in the size of the capital stock, thereby raising the pretax (and post-tax) rate of return per unit of capital. Since both of these effects apply equally to households and pensions, the net yield differential caused by the tax on nominal capital gains remains. Even in the absence of inflation, pensions can earn a higher yield on equities than households can. The fact that pensions attract a substantial part of personal saving but not all of it suggests that there is a positive but less than infinite elasticity of substitution between pension saving and direct saving. The increase in the yield spread in favor of pensions should therefore cause pensions to have a larger share of the total private saving. Of course,

1 An explicit analysis of the effect of inflation on equity yields of households and pension funds is presented in Feldstein $(1980 \mathrm{a}, \mathrm{b})$.

2 In the extreme case, the yield per dollar of equity capital might remain permanently constant. Munnell (1979) apparently ignores the capitalization effect and therefore concludes incorrectly that the equity yield per dollar of invested funds will fall by as mach as the decline in the equity yield per unit of capital. 
because the effective tax rate on capital gains is relatively small, the advantage of the switch is also small and the redistribution of assets would not be large. ${ }^{1}$ It would nevertheless be in the direction of increasing and strengthening the role of private pensions.

\subsection{A Debt-Only Economy}

Consider now a debt-only economy, or at least an economy is which all marginal corporate investments are financed by debt, ${ }^{2}$ and pension funds invest exclusively in debt. The effect of a change in inflation in such an econoriy is both more complex and more dramatic than in the all equity econony. The precise nature of the effect depends on the way that the interest rate responds to inflation.

The stylized "fact" that the real interest rate remains constant is a useful starting point. 3 Since pension funds are not taxed, a constant real rate of interest implies that they earn a constant real net rate of interest. In contrast, the real net yield earned by households drops sharply for each percentage point rise in the rate of inflation. If the rate of tax paid by households is $\theta$, the real net interest rate is $r_{h}=(1-\theta) i-\pi$ where $i$ is the nomi-

1 The inflation-induced growth of the assets of pension funds would also be reduced to the extent that households save less in response to the lower real yield on saving or divert saving into nonportfolio assets like housing and land.

2 Joseph Stiglitz (1973) develops an analysis which shows that under certain conditions such debt-at-the-marjin behavior is optimal under U.S. tax laws.

3 Although Irving Fisher's (1930) theoretical support for the independence of inflation and the real interest rate is no lonser valid in an economy with a complex tax structure, the combination of tax rules and government debt policy can achieve an approximately constant real rate of return; see Feldstein (1980c). 
nal rate, $\pi$ is the rate of inflation, and the $h$ subscript refers to the return to households. Thus $d r_{h} / d \pi=(1-\theta)\left(d i / d_{\pi}\right)-1=-\theta$ when $d i / d \pi=1$. If the individual tax rate averages 30 percent $(\theta=.3)$, the real net interest rate would fall from 2.8 percent when there is a 4 percent nominal interest rate and no inflation to 1.0 percent when there is 6 percent inflation and a 10 percent interest. rate. The yield difference between pension funds (earning a real 4 percent in both cases) and direct saving nearly triples from 1.2 percent to 3.0 percent. In this "Fisherian" economy, inflation again strengthens the relative position of pension saving. The absolute real yield remains unchanged and the relative real yield encourages the substitution of pension saving for regular direct saving.

An alternative simple view is that the nominal interest rate is determined as the yield that corporations can afford to pay with a fixed real return on capital( $\left.f^{\prime}\right) .1$ The firms' first-order condition is readily shown to be: ${ }^{2}$

(1) $\quad f^{\prime}+\pi=\tau f^{\prime}+\tau \mu \pi+(1-) i$.

1 This ignores the influence of noncorporate borrowers, government debt policy, and international capital flows.

2 This is a special case of the result derived in Feldstein, Jerry Green and Eytan Sheshinski (1978). 
The nominal pretax return per unit of capital $\left(f^{\prime}+\pi\right)$ is exhausted by the tax on the real return on capital ( $\tau f^{\prime}$ where $\tau$ is the corporate tax rate) plus the tax on the nominal gains that results from historic cost depreciation ( $\tau \mu \pi$ where $\mu$ measures the increase in taxable profits on a unit of capital per percentage point increase in inflation), 1 plus the maximum net yield on $\operatorname{debt}((1-\tau) i)$. Thus the nominal interest rate is given by

$$
i=f^{\prime}+\frac{1-\mu \tau}{1-\tau} \pi
$$

With $\mathrm{f}^{\prime}$ constant, $\mathrm{di} / \mathrm{d} \pi=(1-\mu \tau) /(1-\tau)$. The value of $\mu$ depends on the rate of inflation but a reasonable approximation is $\mu=0.5$ (see Feldstein, 1980b, especially the appendix). Thus with the current 46 percent corporate tax rate, $\mathrm{di} / \mathrm{d} \pi=1.43$. The nominal interest rate rises by more than the increase in inflation, implying that the real yield rises by 43 basis points per percentage point of inflation.

In this case, inflation actually raises the real yield that pension funds can earn. Although this effect also reduces the inflation penalty on household investors, the impact of inflation on the gap between the household return $\left(r_{h}\right)$ and the pension return $\left(r_{p}\right)$ is increased. Since $r_{p}=i-\pi$ while

1 This is a linear approximation and also subsumes the excess taxation of nominal investory profits. 
$r_{h}=(1-\theta) i-\pi, d\left(r_{p}-r_{h}\right) / d \pi=\theta(d i / d \pi)$. With $d i / d \pi=1.43$ and $\theta=0.3$, the real yield spread rises by more than 40 basis points per percentage point of inflation.

In an all debt economy, the truth would probably lie somewhere between the Fisherian constant-real-yield assumption and the alternative positive effect of inflation on the real interest rate. Whatever the exact value, a higher rate of inflation probably raises the real return that pension funds can earn and, by widening the gap between household and pension yields, encourages a greater role for pensions in private saving.

\subsection{An Economy with Debt and Equity}

In a more general economy with both debt and equity capital, the effect of inflation on pension funds is essentially a mixture of the results of the two simpler analyses. ${ }^{1}$. It is now also possible to examine the effect of inflation on the mix of assets that pensions will want to hold.2 To simplify the analysis, I will examine only the 'Fisherian' case in which inflation leaves the real interest rate unchanged and will ignore the long-run effect on the real return on capital $\left(f^{\prime}\right)$ of induced changes in the capital stock.3

1 This assumes that pension funds behave as separate entities. Fisher Black (1980) and Irwin Tepper (1980) have noted that, if pension fund decisions are made as part of the overall corporate financial strategy, it is optimal for the pension fund to hold only debt while the rest of the corporate financial structure is adjusted to achieve the desired debt-equity mix for the corporation-cumpension as a whole.

2 see the previous footnote.

3 Inflation can be expected to reduce capital intensity (under existing tax laws) and therefore to raise the real return on capital. But whatever happens to $f^{\prime}$ does not change the conclusions of this section about the relative attractiveness of debt and equity or of pensions and direct saving. 
In such an economy, a higher rate of inflation reduces the real net rate of return on equity for both households and pensions but the reduction for pensions is less. ${ }^{1}$ The real return on debt remains unchanged for pensions but falls substantially for households $\left(d r_{h} / d \pi=-\theta\right)$. Thus inflation slightly lowers the overall yield on pension funds but, by widening the yield differential in favor of pensions, induces a switch in private saving in favor of pensions.

The relative yields on debt and equity move in opposite directions for households and pensions. For pensions, the real yield on debt is maintained while the real yield on equities falls slightly. For households, the real yield on debt falls sharply while the real yield on equities falls by less. Households thus sell debt to pension funds and hold more equity directly. On balance, it is clear that a positive expected rate of inflation would not be a problem for the private pension system. The real net return earned by pension funds is relatively insensitive to inflation and might actually increase. In any case, the incentive to save through pensions would be strengthened by the increased differential between the yields on direct saving and pension saving.

\section{Inflation and Pension Benefits}

The typical private pension plan provides a retiree with a 'defined benefit', usually some fraction of his average earnings during the five years

1 Feldstein (1980b) presents explicit calculations with realistic values that imply that the equilibrium real net yields on equity (with a constant $f^{\prime}=.112$ ) fall from .0966 for pensions and .0770 for households with no inflation to .0861 for pensions and .0648 for households with a 6 percent inflation. 
before retirement with the fraction proportional to his number of years as an employee of the firm. After retirement, benefits are fixed in nominal dollars; some firms make periodic voluntary adjustments for inflation. Retirees of course find that the real value of their monthly pension benefit is continually reduced by the rising price level.

Constant nominal benefits were obviously designed for an economy with little or no inflation. For an economy with a constant expected rate of inflation, the constant nominal benefits should be replaced by constant real benefits. If the real return earned by the pension fund is unaffected by the rate of inflation, fully indexed benefits would leave the real present-value cost of the pension independent of the inflation rate. ${ }^{1}$

The switch from nominal pensions to indexed pensions would require either a reduction in the starting value of the pension or a reallocation of employees' lifetime incomes from wages to pensions. The amounts are significant; for any given benefit, indexing a single-life annuity for a man age 65 with a 6 percent inflation rate would raise the cost of the pension by approximately 50 percent. This could be financed by a one-third reduction in the starting value

1 In the absence of an indexed pension, a retiree might try to substitute a constant real stream for the constant nominal stream by saving some of the pension benefit in early years. However, since the retiree must pay tax on the interest and dividends that he earns on any such saving, he cannot achieve the equivalent stream. This could be remedied by allowing retirees to "rollover" any part of their pension income into an account where interest and dividends accumulate tax free. 
of the pension, or roughly a 5 to 10 percent decrease in wages, or some combination of the two.

Although employees and firms have not yet faced and resolved this choice, an increasing use of (partially) indexed pensions is likely to evolve in future years. Some reduction in the starting value of the pension would probably be used, especially for long-service employees, to avoid over-pensioning. 1 But on balance the move to indexing is likely to increase the total size of pension saving. ${ }^{2}$

\section{Uncertain Inflation}

The uncertainty of inflation influences the optimal extent of pension indexing and the likely composition of pension assets. It is important to distinguish unanticipated changes in the price level from unanticipated changes in the expected future inflation rate. A one-time rise in the price level (with no change in expected inflation) lowers the real value of nominal assets but leaves the real value of equities unchanged. 3 In contrast, a rise in the expected future rate of inflation leaves the value of short-term bills unchanged but lowers the nominal (and therefore the real) values of bonds and

1 An employee with 30 years service now generally receives a pension equal to 60 percent of his final five-year average earnings. For a retiree with average earnings, social security adds another 46 percent of final year's pay plus 23 percent more for a dependent spouse. The total easily reaches or exceeds 100 percent of real lifetime earnings at a time when family responsibilities, mortgage payments, and the like are relatively low.

2 Partial indexing and a tax-free rollover of pension income as outlined in footnote 18 of page 8 would provide more flexibility and avoid the difficult problem of reducing the initial pension value. Partial indexing of pensions would also increase pension saving by reducing the postponement of retirement.

3 See Feldstein (1980a). 
stocks. 1

Without indexing, the vested pension obligations are nominal long-term liabilities of the firm. The firm can hedge these liabilities by holding longterm bonds. 2 of course, firms may nevertheless invest in equities because they believe that the equity yield is high enough to compensate for the reduced hedging. 3 But, since the extra risk of equity investment is borne by the firm's shareholders, the employees who participate in the pension plan should earn an implicit nominal return on their forgone wages that is only equal to the nominal return on riskless bonds.

A fully indexed pension would make all pension obligations real. Long-terin bonds are clearly an inappropriate investment for funding such real obligations. Stocks can provide a hedge against price level uncertainty, but only by accepting substantial general uncertainty. Zvi Bodie (1980) has emphasized that a portfolio with a minimum-variance real return would be invested almost completely in short-term debt (with a small amount in commodity futures) and that the expected return on such a portfolio is approximately zero. If employees are so risk averse that they choose a fully indexed pension, the

1 see Feldstein (1980a) for an explanation of why stocks respond in this way to changes in the price level and the rate of inflation.

2 Jeremy Bulow (1980) emphasizes the very sharp distinction between vested and other anticipated pension liabilities, although not in relation to the current issue.

3 For the reasons given by Black and Tepper, this equity investment might be done in the corporation itself with offsetting corporate borrowing. I shall not, in the remaining paragraphs, distinguish investment in the firm from investment in the pension portfolio. 
implicit real return that they earn on forgone wages should therefore also be approximately zero. Again, firms may invest in equities, but the shareholders rather than the pensioners should receive any extra yield in return for bearing that risk.

If employees choose a partially indexed pension, i.e., one in which benefits rise less than one-for-one with the price level or in which benefits depend on the return on the pension fund assets, the firm can invest in a way that permits giving a higher return to pension participants while compensating shareholders for any additional risk that they bear. The optimal extent of pension indexing depends on the risk aversion of employees and the cost, in terms of the reduction in the expected yield, of investing pension assets to produce a constant real return.

As Paul Samuelson (1958) noted years ago, an unfunded social security program can provide an annuity with an implicit real rate of return equal to the real growth rate of the economy, probably about 3 percent a year over the next decade or longer. Although 3 percent is substantially less than the real return of more than 10 percent that the national as a whole earns on additions to the stock of plant and equipment (Feldstein and Poterba, 1980), the political pressure to substitute unfunded social security benefits for private pensions (or vice versa) is likely to depend on the real after-tax yield that partly indexed pensions can offer and on the associated risk. If employees were completely risk averse, the low 3 percent yield on social security would look good in comparison to Bodie's zero yield on a minimum-variance real return portfolio. But if employees are willing to accept the risk inherent in a par- 
tially indexed pension, they can expect to receive an implicit yield that is much greater than three percent.l

In summary, the form and funding of private pensions will probably change in the coming decade if inflation continues at recent levels but, unless employees become much more risk averse, private pensions are likely to continue to finance a growing share of retirement consumption.

Cambridge, Massachusetts

August 1980, Revised September 1980

1 This yield will of course depend on both the performance of the economy and the changes in tax laws. In particular, indexed depreciation would reduce the riskiness of equity investment (by reducing the sensitivity of share prices to the expected rate of inflation) and increase its expected return. 


\section{$\underline{\text { References }}$}

Fischer Black, "The Tax Advantages of Pension Fund Investments in Bonds," NBER Working Paper No. 533, 1980.

Zvi Bodie, "Purchasing Power Annuities: Financial Innovation for Stable Real Retirement Income in an Inflationary Environment," NBER Working Paper No. 442, 1980.

Jeremy Bulow, "Analaysis of Pension Funding Under ERISA," NBER Working Paper No. $402,1979$.

Martin Feldstein, "Inflation and the Stock Market," American Economic Review, forthcoming, 1980a. (NBER Working Paper No. 276). , "Inflation, Tax Rules and the Stock Market," Journal of Monetary Economics, Vol. 6., pp. 309-31, 1980b. (NBER Working Paper No. 403).

, "Fiscal Policies, Inflation and Capital Formation," American Economic Review, forthcoming, 1980c. , Jerry Green, and Eytan Sheshinski, "Inflation and Taxes in a Growing Economy with Debt and Equity Finance," Journal of Political Economy, April 1978, 86, No. 2, Part 2, S53-S70. and James Poterba, "State and Local Taxes and the Rate of Return on Non-Financial Corporate Capital," NBER Working Paper No. $508,1980$.

and Lawrence Surnmers, "Inflation and the Taxation of Capital Income in the Corporate Sector," National Tax Journal, December 1979, Vol. XXXII, No. 4, 445-70.

Irving Fisher, The Theory of Interest, New York, 1930. 
Alicia H. Munnell, "The Impact of Inflation on Private Pensions," New England Economic Review, March/April 1979, 18-31.

Paul A. Samuelson, "An Exact Consumption-Loan Model of Interest with or Without the Social Contrivance of Money," Journal of Political Economy, December 1958, 66, 467-82.

Joseph Stiglitz, "Taxation, Corporate Financial Policy, and the Cost of Capital," Journal of Public Economics, February 1973, Vol. 2, No. 1, $1-34$.

Irwin Tepper, "Taxation and Corporate Pension Policy," mimeo., 1980. 